generations of geographers and historians of science in Spain, Latin America, and beyond as a comprehensive and rigorous guide to the history of their chosen fields. Over thirty years later his extensive bibliography remains relevant, and his incisive readings of the works he surveys stand to this day as an example of the highest level of scholarship in the history of geography. ${ }^{2}$

${ }^{2}$ Capel continued working on the history of geography in three subsequent books focused on the development of the field in Spain. Of his numerous articles on history and geography, many were published in the journal Geo Crítica and subsequently in Scripta Nova. He is Professor Emeritus at the University of Barcelona, where he worked from 1967 until 2011.

\title{
The History of Geography: Narratives to Discipline the Past and Reinvent Geography as a Modern Discipline
}

\author{
Carla Lois
}

$\mathrm{H}$ oracio Capel, born in Málaga in 1941, is one the most influential figures in the Spanishspeaking geographical community. After obtaining the degree of licenciado in philosophy and letters at the University of Murcia in 1962, he got his Ph.D. in geography at the University of Barcelona; he has enjoyed a remarkable career as a professor and researcher at the University of Barcelona. Capel played a very active role training students and young scholars. He was especially enthusiastic in advising Latin American geographers: by the end of the twentieth century, more than two generations of geographers had been deeply influenced by his ideas. Capel maintained a close personal involvement with Latin American universities, especially in Mexico, Brazil, and Argentina.

His commitment to the geographical community is manifest: he organized many international conferences, he promoted international exchanges, and he created a touchstone among Ibero-American academic journals in 1976, in what could be considered one of his most important legacies: Geo Crítica, a prestigious journal that is still active today. ${ }^{1}$

Capel's Filosofía y ciencia en la geografía contemporánea was published in $1981 .{ }^{2}$ Although in recent years Capel has been better known for his studies in urban geography, in the 1980s he investigated and published a series of reflections on the history, historiography, and philosophy of geography. This book is by no means a minor contribution: geography and geographers have a complex relationship with the past of the discipline; during the twentieth century geography has been consolidated as a "science of the present," and there seems to be little willingness within the

Carla Lois, licenciada in geography, holds a Ph.D. in history. She is now a researcher at the Consejo Nacional de Investigaciones Científicas y Técnicas (CONICET) and a professor at the University of Buenos Aires. She coordinates the working group "Historia y Epistemología de la Cartografía" (UBA) and is an Associate Editor for Volume 5 of "The History of Cartography Project," under way at the University of Chicago Press.

${ }^{1}$ The journal's website is http://www.ub.edu/geocrit/menu.htm.

${ }^{2}$ Horacio Capel, Filosofía y ciencia en la geografía contemporánea: Una introducción a la geografía (Barcelona: Barcanova, 1981). 
discipline to look back. This book was in fact one of the few comprehensive examinations of the history of geography at the time.

Filosofía y ciencia narrates the modern history of geography; it is a history written by a geographer for geographers. Beginning with a couple of short chapters on origins, Capel tells us about two men he called the "symbolic" fathers of the discipline, the emblematic figures Alexander von Humboldt (1769-1859) and Carl Ritter (1779-1859).

The second part (six chapters) presents a careful study of the processes of the institutionalization of geography in Europe, focused on Germany, France, Great Britain, and Russia in the last decades of the nineteenth century. These chapters form the core of the book's historiographical approach: they explore how geography came into universities and became a modern science.

The third part (five chapters) describes the "philosophy of geography"; it follows a simplistic Kuhnian model by presenting a chronology of predominant theories, ideas, and perspectives, but without avoiding all the conflicts concerning the "dualism" of geography in every paradigm.

The simplicity of the book's structure and narrative is one of its strongest points, particularly given that it was conceived as a textbook. Such a book was necessary in the field at the time for several reasons; explaining this requires some context.

First, when Filosofía y ciencia en la geografía contemporánea appeared there was no history of geography published in Spanish. Even though the book is written from a very European point of view (some Latin Americans, especially Brazilians, would soon challenge the prevalence of European approaches), the author is a Spanish speaker and his books were and are read by a broad audience beyond Spain's frontiers.

Second, somehow the book appeared at the right moment to respond to one of the discipline's biggest problems: the lack of a clear identity. As Anne Godlewska observes: “Toward the end of the eighteenth century, the community of geographers entered a troubled period. This 'trouble' consisted of a loss of direction and a perceived real loss of status among the 'sciences humaines.' "Incidentally, this problem can still be seen today when geographers are asked what geography is and have no clear answer at the ready. Capel's narrative, as selective and biased as any other, nonetheless builds up a modern identity for the discipline that linked it to other modern disciplines (in Foucauldian terms). He took as a starting point disciplined knowledge produced under specific rules at established institutions, notably universities. The book engages with all those attempts to demonstrate the scientificity of geographical knowledge. Creating a past or "inventing a tradition" (Eric Hobsbawm) is a way to create identities. ${ }^{3}$ If this past has things in common with others (in this case, with the pasts of other disciplines), that identity is reinforced by the sense of "belonging" to something larger (here, the scientific community). In that context, old-fashioned geographical methods (exploration, description, etc.) tended to be replaced by logical and positivistic approaches.

The bias favoring institutionalized geography as a modern discipline becomes clear when we note that Capel omitted or minimized the crucial circumstance that older geographers who had been active in socially influential geographical societies were in fact the very figures who took those celebrated first chairs offering isolated courses in geography at European universities. For what is often presented as "the institutionalization" of geography in the late nineteenth century was not the founding of departments of geography, the creation of a career path at universities, or the granting of degrees in geography but, rather, the emergence of new courses in different kinds of geography run by historians, geologists, zoologists, and others. The importance

\footnotetext{
${ }^{3}$ Anne Marie Claire Godlewska, Geography Unbound: French Geographic Science from Cassini to Humboldt (Chicago: Univ. Chicago Press, 1999), p. 57; and Eric Hobsbawm and Terence Ranger, eds., The Invention of Tradition (Cambridge: Cambridge Univ. Press, 1983).
} 
of these courses tends to be magnified to establish a watershed between the "prescientific period" and "scientific geography." Indeed, geographical societies (which multiplied around the world during the nineteenth century) were considered by Capel and many others to be nonscientific groups; here they saw a contrast with the older academies of sciences that preceded the organization of their respective modern disciplines, which adopted new identities and retained their prestige, traditions, and social recognition (now many of them are museums, botanical gardens, etc.).

From the 1970s until the end of the twentieth century, histories of geography flourished. The following works were the most influential in the Spanish-speaking academies: Paul Claval, Evolution de la géographie humaine (1964); Milton Santos, Por uma geografía nova (1978); Josefina Gómez Mendoza, Julio Muñoz Jiménez, and Nicolás Ortega Cantero, El pensamiento geográfico: Estudio interpretativo y antología de textos (1982); Antonio Carlos Moraes, Geografía: Pequeña história crítica (1983); Tim Unwin, The Place of Geography (1992); David Livingstone, The Geographical Tradition (1992); and José Ortega Valcárcel, Los horizontes de la geografía (2000). ${ }^{4}$ This flourishing can be understood as a symptom of the need to reconsider the narratives of the past of the discipline.

These publications opened my mind to new historiographical perspectives with which I felt more empathy. And so I turned away from Filosofía y ciencia for a time. My main criticism was that Capel's book established a clear turning point with Humboldt and Ritter and their followers, without mentioning the earlier history of geographical thought. This rupturist option neglected the most brilliant periods in the production of geographical knowledge, including antiquity and the Renaissance, in the Western world and elsewhere. Moreover, I am convinced that geography used to be more widely recognized as necessary for understanding the world before its institutionalization in universities. In others words: in the nineteenth century, geography became an "undisciplined discipline."

However, taking a second look many years later, and setting aside my own personal historiographical approach, I find that - even though nearly four decades have elapsed since its first publication - Filosfía y ciencia en la geografía contemporánea continues to be an essential reference work. It is fundamental for beginning an exploration of the history of geography because it is a consistent, coherent, solid, and well-documented historiographical book that still amply repays reading and study.

As a student of geography at the University of Buenos Aires, one of the first courses I took was "Theories and Methods in Geography I (1870-1950)." At that time, the course was mandatory for all students of geography, and Capel's Filosofía y ciencia was the primary text. Twenty years later I myself began teaching the course, now called "Contemporary Theories in Geography I (1870-1950)" - but it is no longer mandatory. Even worse: it is an optional class for advanced students. Every year, at the beginning of the semester, I experience the same feeling: I am more and more surprised that students so close to becoming professional geographers themselves completely ignore what geographers in the past - that is, anything more than thirty years ago! - used to do. And we, as professors, have the opportunity to fill this gap only for those few students who choose to take the course. Sadly, the majority of young geographers will remain in the dark about the history of their discipline.

\footnotetext{
${ }^{4}$ Paul Claval, Evolution de la géographie humaine (Paris: Les Belles Lettres, 1964); Milton Santos, Por uma geografía nova: Da crítica da geografia a uma geografia crítica (Sao Paulo: HUCITEC, 1978); Josefina Gómez Mendoza, Julio Muñoz Jiménez, and Nicolás Ortega Cantero, El pensamiento geográfico: Estudio interpretativo y antología de textos (Madrid: Alianza, 1982); Antonio Carlos Moraes, Geografía: Pequeña história crítica (Sao Paulo: HUCITEC, 1983); Tim Unwin, The Place of Geography (London: Routledge, 1992); David Livingstone, The Geographical Tradition (Cambridge, Mass.: Blackwell, 1992); and José Ortega Valcárcel, Los horizontes de la geografía (Barcelona: Ariel, 2000).
} 
Geographers of my generation (and a couple of others) are in debt to Horacio Capel for saving us from such an embarrassing state of ignorance and for making us familiar with the past of the discipline. For this reason, at least (but not only for this), all criticism of Filosfía y ciencia en la geografía contemporánea must be tempered by recognition of how original, risky, and positively ambitious this project was in the early 1980s. In fact, we should thank Capel for the inspiration that moved other Latin American scholars to think about and indeed to write histories of geography from "this side of the Atlantic" perspectives.

As a professor now, I teach my students to read the tables of contents of several histories of geography in order to identify the authors' approaches and perspectives. And some of the chapters of Filosofía y ciencia en la geografía contemporánea are included in my syllabus as obligatory readings. Moreover, I recommend that students read the book at several times at different points in their careers and scholarly endeavors. They will always find something new in it to keep them inquiring into the history of geography, and it continues to inspire new questions about the past that help us to understand the present of this undisciplined discipline. 